\title{
Three-component reactions of kojic acid: Efficient synthesis of Dihydropyrano[3,2-b]chromenediones and aminopyranopyrans catalyzed with Nano-Bi2O3-ZnO and Nano-ZnO
}

\author{
Maryam Zirak $^{\mathrm{a}^{*}}$, Mostafa Azinfar ${ }^{\mathrm{a}}$ and Mosleh Khalili ${ }^{\mathrm{a}}$
}

${ }^{a}$ Department of Chemistry, Payame Noor University, Iran

\begin{tabular}{l}
\hline C H R O N I C L E \\
\hline Article history: \\
Received January 2, 2017 \\
Received in revised form \\
March 1, 2017 \\
Accepted April 21, 2017 \\
Available online \\
April 22, 2017 \\
\hline Keywords: \\
Kojic acid \\
Heterogeneous catalysis \\
Multicomponent reaction \\
Solvent-free \\
Nano-ZnO \\
\hline
\end{tabular}

\begin{abstract}
A B S T R A C T
Synthesis of pyrano-chromenes and pyrano-pyrans was developed by three-component reactions of kojic acid and aromatic aldehydes with dimethone and malononitrile, catalyzed with nano- $\mathrm{Bi}_{2} \mathrm{O}_{3}-\mathrm{ZnO}$ and nano- $\mathrm{ZnO}$, respectively. Reactions proceeded smoothly and the corresponding heterocyclic products were obtained in good to high yields. Nano $\mathrm{ZnO}$ and nano $\mathrm{Bi}_{2} \mathrm{O}_{3}-\mathrm{ZnO}$ were prepared by sol-gel method and characterized by X-ray diffraction (XRD), energy-dispersive X-ray analysis (EDX), Fourier transform infrared (FT-IR), scanning electron microscopy (SEM), and transmission electron microscopy (TEM) techniques. Supporting $\mathrm{Bi}^{3+}$ on $\mathrm{ZnO}$ nanoparticles as $\mathrm{Bi}_{2} \mathrm{O}_{3}$, is the main novelty of this work. The simple reaction procedure, easy separation of products, low catalyst loading, reusability of the catalyst are some advantageous of this protocol.
\end{abstract}

\section{Introduction}

Multi-component reactions (MCRs) have been attracted a lot of attention in organic and pharmaceutical chemistry because of the construction of biologically active compounds. ${ }^{1}$ Although, these reactions are complicated than stepwise reaction, they are fast, efficient and environmentally favorable methods.

Chromenes and pyrano-pyranes are important classes of fused oxygenated heterocycles ${ }^{2}$ with a wide range of biological and therapeutic properties, such as antibacterial, ${ }^{3}$ anti-cancer, ${ }^{4}$ antianaphylactic, ${ }^{5}$ and anticonvulsant activities. ${ }^{6}$ Also, they are extensively found in natural products, such as biscopyran, ${ }^{7}$ Elatenyne, ${ }^{8}$ Calyxin I, Calyxin J, and Epicalyxin J. ${ }^{9}$ Therefore, the development of efficient and convenient methods for the synthesis of chromene and pyranopyran derivatives using a recyclable and environmentally benign catalyst is very necessary. Three-component reaction of kojic acid, aldehyde and 1,3-dicarbonyl compounds or malononitrile is one of the most important methodology for the synthesis of these heterocyclic systems. A various catalysts and conditions were

* Corresponding author.

E-mail address: m.zirak@pnu.ac.ir (M. Zirak)

(C) 2017 Growing Science Ltd. All rights reserved.

doi: 10.5267/j.ccl.2017.4.001 
reported for this reaction, including $\mathrm{InCl}_{3},{ }^{10} \mathrm{CAN},{ }^{11} \mathrm{Al}_{2} \mathrm{O}_{3},{ }^{12} \mathrm{Bi}(\mathrm{OTf})_{3},{ }^{13} \mathrm{CeCl}_{3} \cdot 7 \mathrm{H}_{2} \mathrm{O} / \mathrm{SiO}_{2},{ }^{14} \mathrm{FeCl}_{3}-$ $\mathrm{SiO}_{2},{ }^{15} \mathrm{Fe}_{3} \mathrm{O}_{4} @ \mathrm{SiO}_{2},{ }^{16}$ ultrasonic irradiation, ${ }^{17}$ imidazole, ${ }^{18}$ piperidine, ${ }^{19} \mathrm{Et}_{3} \mathrm{~N},{ }^{20}$ and $\mathrm{NH}_{4} \mathrm{VO}_{3} .{ }^{21} \mathrm{Kojic}$ acid and its derivatives have wide range of applications in cosmetic, ${ }^{22}$ medicine, ${ }^{23}$ food, ${ }^{24}$ agriculture ${ }^{25}$ and chemical industries. ${ }^{26}$

In the other hand, metal oxides play a crucial role in many areas of chemistry, physics and materials science. ${ }^{27}$ Recently, heterogeneous catalysis using metal oxides has been attracted great attention due to their potential applications in organic synthesis. ${ }^{28-29}$ Among them, bismuth and zinc oxides are as effective catalysts because of their low toxicity, ease of handling, low cost and relative insensitivity to air and moisture. ${ }^{30}$

In continuing our works on the heterocyclic chemistry, ${ }^{31-33}$ we report herein a one pot three-component synthesis of chromenes and pyranopyarns from kojic acid catalyzed by nano- $\mathrm{Bi}_{2} \mathrm{O}_{3}-\mathrm{ZnO}$ and nano$\mathrm{ZnO}$, respectively.

\section{Results and Discussion}

$\mathrm{ZnO}$ nanoparticles were prepared using a polyethylene glycol (PEG) sol-gel method as reported by Amini et al., ${ }^{34}$ by heating a solution of $\mathrm{Zn}\left(\mathrm{NO}_{3}\right)_{2}$ and $\mathrm{PEG}$ in $\mathrm{EtOH}$ until forming a viscous gel, followed by drying and calcination in air at $500{ }^{\circ} \mathrm{C}$. Then, $\mathrm{Bi}_{2} \mathrm{O}_{3}-\mathrm{ZnO}$ nanoparticles were prepared by adding nano-ZnO to a solution of $\mathrm{BiCl}_{3}$ in $\mathrm{MeOH}$ for $24 \mathrm{~h}$, and drying in air at room temperature. Obtained nano- $\mathrm{ZnO}$ and nano- $\mathrm{Bi}_{2} \mathrm{O}_{3}-\mathrm{ZnO}$ were characterized using FT-IR, SEM, XRD, EDX and TEM analysis. $\mathrm{XRD}$ pattern of the nano- $\mathrm{ZnO}$ shows peaks at the positions of $31.63^{\circ}, 34.31^{\circ}, 36.11^{\circ}, 47.48^{\circ}, 56.55^{\circ}$, $62.80^{\circ}, 66.33^{\circ}, 67.90^{\circ}$ and $69.04^{\circ}$, which are in good agreement with reported data. ${ }^{34}$ In addition to peaks related to nano- $\mathrm{ZnO}$, peaks at the positions of $32.78^{\circ}, 33.47^{\circ}, 37.86^{\circ}, 44.77^{\circ}$ was appeared in the XRD pattern of the nano- $\mathrm{Bi}_{2} \mathrm{O}_{3}-\mathrm{ZnO}$, accounted to the existence of $\beta-\mathrm{Bi}_{2} \mathrm{O}_{3}{ }^{35}$ in the composition of nanoparticles (Fig. 1.).

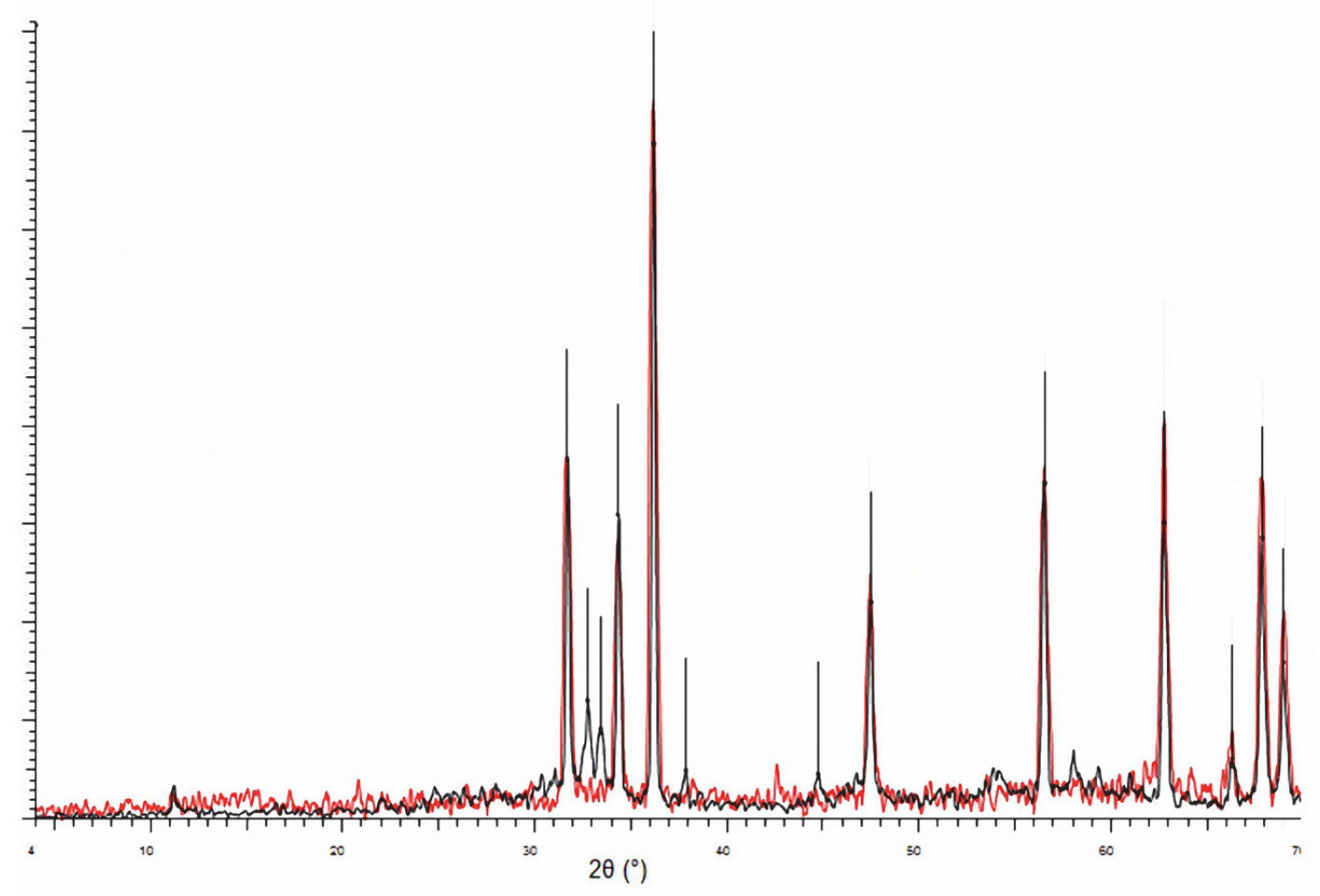

Fig. 1. XRD patterns of nano- $\mathrm{ZnO}$ (red) and nano- $\mathrm{Bi}_{2} \mathrm{O}_{3}-\mathrm{ZnO}$ (black) 
FT-IR spectrum of nano-ZnO shows peaks at 842 and $543 \mathrm{~cm}^{-1}$ that are related to the stretching and bending vibrations of $\mathrm{O}-\mathrm{Zn}-\mathrm{O}$ bonds. The peaks of the bending and stretching vibrations of $\mathrm{O}-\mathrm{H}$ were appeared at 1620 and $3415 \mathrm{~cm}^{-1}$, respectively. Peaks at 2877 and 2910 and $1103 \mathrm{~cm}^{-1}$ are attributed to vibrations of $\mathrm{CH}_{2}$ and $\mathrm{C}-\mathrm{O}$ bond of PEG precursor. In the FT-IR spectrum of nano- $\mathrm{Bi}_{2} \mathrm{O}_{3}-\mathrm{ZnO}$, peaks at 3451 and $1623 \mathrm{~cm}^{-1}$ are attributed to the vibrations of O-H. Peaks around 906 and 726 and $481 \mathrm{~cm}^{-1}$ corresponds to the stretching vibrations of $\mathrm{Zn}-\mathrm{O}$ and $\mathrm{Bi}-\mathrm{O}$ and bending vibrations of $\mathrm{O}-\mathrm{Bi}-\mathrm{O}$, respectively (Fig. 2.).

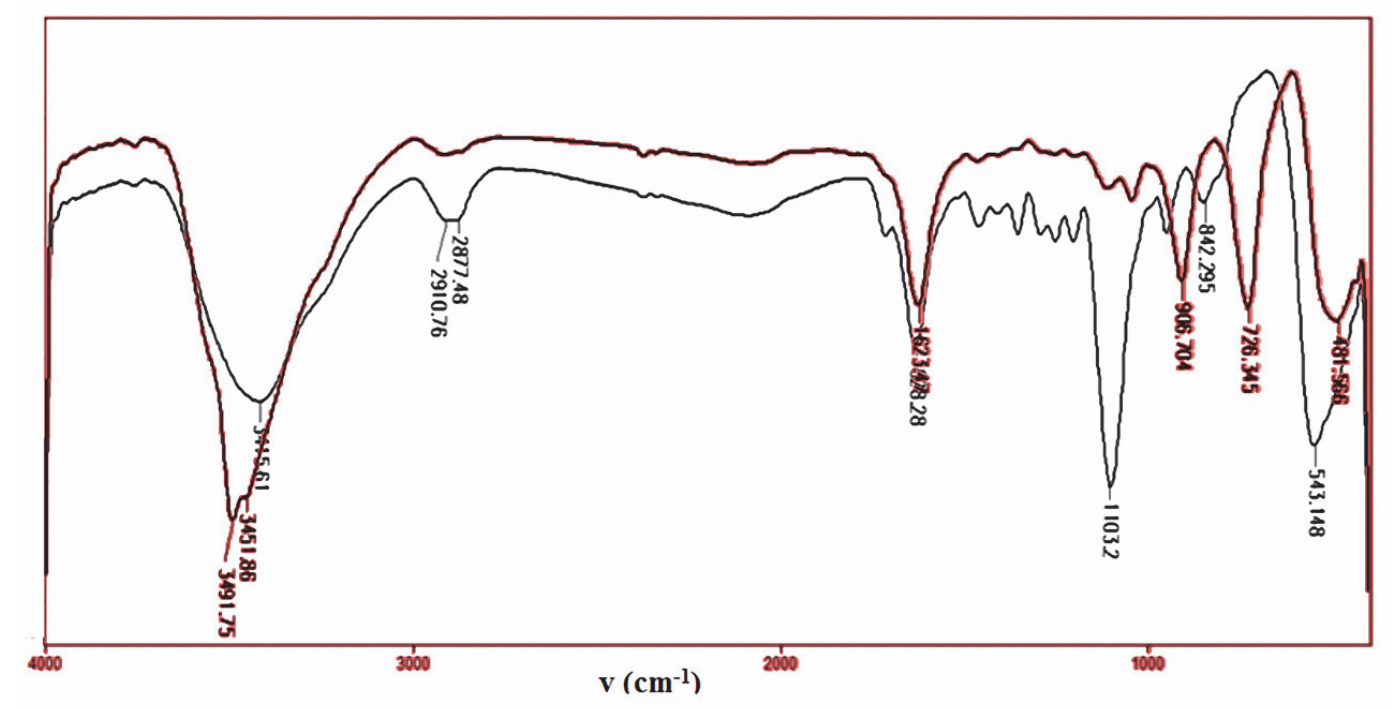

Fig. 2. FT-IR spectra of $\mathrm{ZnO}$ (black) and $\mathrm{Bi}_{2} \mathrm{O}_{3}-\mathrm{ZnO}$ (red) nanoparticles

Particle morphology and textural properties of nano- $\mathrm{ZnO}$ and nano- $\mathrm{Bi}_{2} \mathrm{O}_{3}-\mathrm{ZnO}$ catalysts were studied by SEM and TEM images, in which the nanoparticles of $\mathrm{ZnO}$ were appeared as regular geometric shapes such as cubic and rod like materials (Fig. 3a.). SEM images of $\mathrm{Bi}_{2} \mathrm{O}_{3}-\mathrm{ZnO}$ showed the similar shape with nano-ZnO with Puffy and wrinkled surface (Fig. 3b.). TEM images of $\mathrm{Bi}_{2} \mathrm{O}_{3}-$ $\mathrm{ZnO}$ revealed that the existence of $\mathrm{ZnO}$ nanoparticles with very tiny particles of $\mathrm{Bi}_{2} \mathrm{O}_{3}$ on its surface (Fig. 3c,d.). Energy dispersive X-ray analysis was used for the elemental analysis of nanoparticles. EDX data of nano $\mathrm{ZnO}$ showed the weight percentage of $89.85 \%$ and $10.15 \%$ of $\mathrm{Zn}$ and $\mathrm{O}$, respectively. EDX analysis of $\mathrm{BiCl}_{3}-\mathrm{ZnO}$ composite did not exhibit the $\mathrm{Cl}$ in the structure, where the $\mathrm{Zn}, \mathrm{Bi}$ and $\mathrm{O}$ weight percentage were determined as $69.39 \%, 19.28 \%$ and $11.33 \%$, respectively, indicating the formation of nanoparticles of $\mathrm{Bi}_{2} \mathrm{O}_{3}$ by hydrolysis of $\mathrm{BiCl}_{3}$ with water molecules on the surface of nano- $\mathrm{ZnO}$ in $\mathrm{MeOH}$.

The catalytic activity of the prepared nano- $\mathrm{Bi}_{2} \mathrm{O}_{3}-\mathrm{ZnO}$ was investigated by reacting of dimethone and benzaldehyde with 1.1 equiv. of kojic acid in the presence of catalytic amount of nano- $\mathrm{Bi}_{2} \mathrm{O}_{3}-\mathrm{ZnO}$ in EtOH under reflux conditions for $6 \mathrm{~h}$, leading to corresponding chromene 3a in $40 \%$ yield (Table 1, Entry 1). Increasing the reaction time did not improve the yield. In order to obtain the best reaction conditions, the reaction was carried out in different solvents under reflux conditions, such as water, $\mathrm{MeCN}, \mathrm{CH}_{2} \mathrm{Cl}_{2}$ and solvent-free conditions (Entries 2-5). In water Knoevenagel product 4 was obtained as major product along with the desired product in very low yield. However, reaction in MeCN did not occur. In $\mathrm{CH}_{2} \mathrm{Cl}_{2}, 23 \%$ of desired product $3 \mathbf{a}$ was obtained. Heating a mixture of kojic acid, dimethone and benzaldehyde in the presence of catalytic amount of nano- $\mathrm{Bi}_{2} \mathrm{O}_{3}-\mathrm{ZnO}$ at $100{ }^{\circ} \mathrm{C}$ under solvent-free conditions for $2 \mathrm{~h}$, furnished the chromene 3a in 80\% yield (Entry 5). By decreasing the reaction temperature (Entries 5-8), not only the reaction time was increased, but also the yield was decreased, as there is no product detected at room temperature after $8 \mathrm{~h}$. When reaction was conducted at elevated temperature $\left(110{ }^{\circ} \mathrm{C}\right)$, the product $3 \mathbf{a}$ was obtained in $66 \%$ along with formation of a mixture of nonisolable colored complex byproducts (Entry 9). In order to determine the optimum amount of catalyst, 
similar reaction was performed in the presence $0.01,0.02,0.03$ and $0.05 \mathrm{~g}$ of nano- $\mathrm{Bi}_{2} \mathrm{O}_{3}-\mathrm{ZnO}$ catalyst, from which the $0.03 \mathrm{~g}$ of catalyst was selected for the best result (Entries 5, 11-13). In the absence of nano- $\mathrm{Bi}_{2} \mathrm{O}_{3}-\mathrm{ZnO}$ catalyst, reaction did not afford the desired product (Entry 10). When reaction was conducted using nano- $\mathrm{ZnO}$, chromene 3a was obtained only in $20 \%$ isolated yield, with a complex mixture of byproducts, as monitored by TLC (Entry 14). To investigate the effect of $\mathrm{Bi}^{3+}$, reaction was also applied in the presence of $\mathrm{BiCl}_{3}(5 \mathrm{~mol} \%)$, resulted in formation of octahydroxanthene 5 as major product, along with formation of desired product in low yield (Entry 15). Recoverability of the catalyst was studied by separation of catalyst by simple filtration, followed by washing with $\mathrm{CH}_{2} \mathrm{Cl}_{2}$ three times, and then drying at $50{ }^{\circ} \mathrm{C}$ under vacuum. The remaining catalyst reloaded with fresh reagents under the reaction conditions for four further runs, in which no considerable decrease in the yield was observed, demonstrating that nano- $\mathrm{Bi}_{2} \mathrm{O}_{3}-\mathrm{ZnO}$ can be reused as a catalyst (Entry 5).
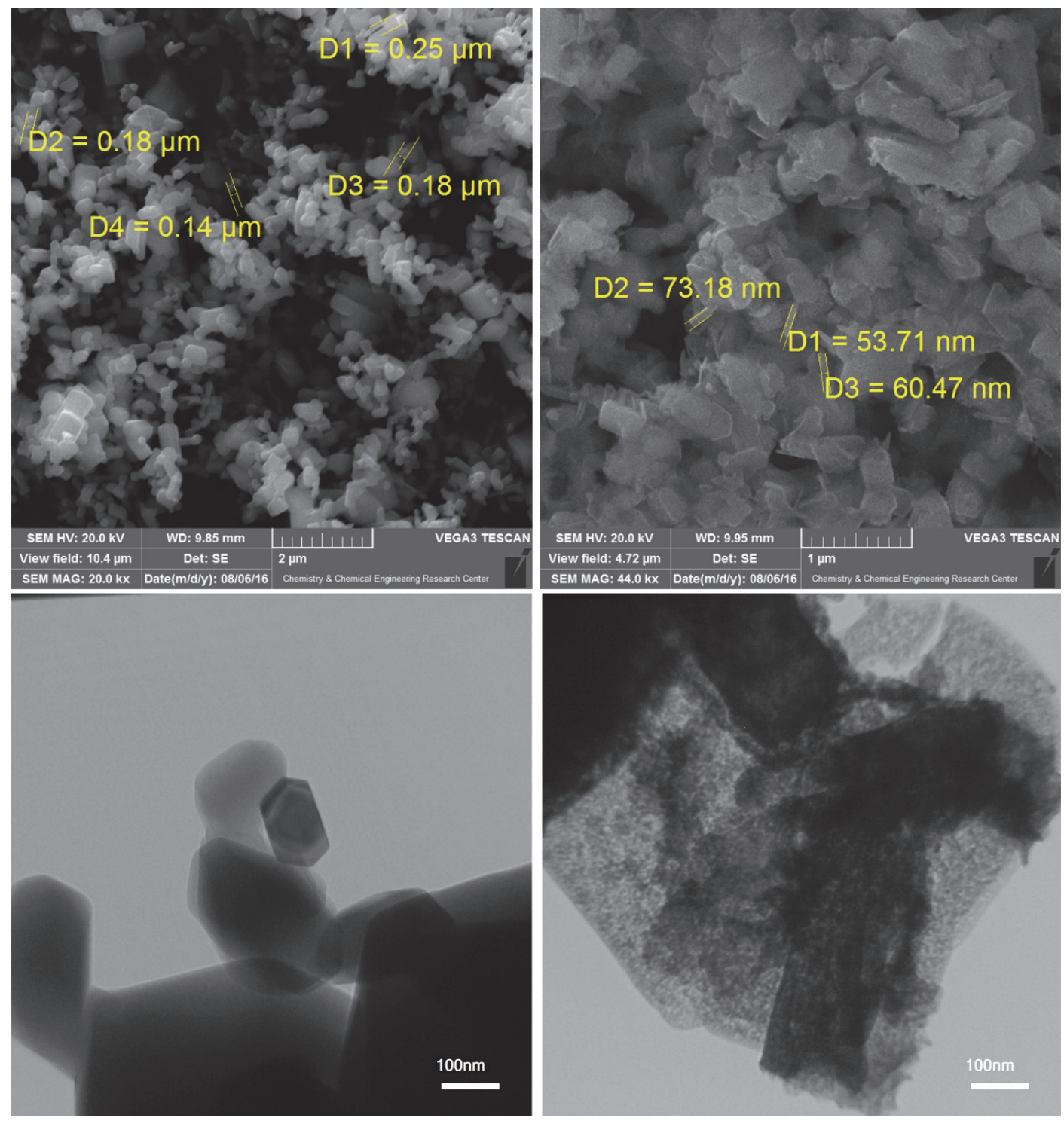

Fig. 3. SEM images of (a) $\mathrm{ZnO}$ and (b) $\mathrm{Bi}_{2} \mathrm{O}_{3}-\mathrm{ZnO}$ nanoparticles and TEM images of (c) $\mathrm{ZnO}$ and (d) $\mathrm{Bi}_{2} \mathrm{O}_{3}-\mathrm{ZnO}$ nanoparticles

With optimum conditions in hand, nano- $\mathrm{Bi}_{2} \mathrm{O}_{3}-\mathrm{ZnO}$ catalyzed three component synthesis of chromene derivatives were investigated using various substituted benzaldehydes (Scheme 1). Reactions were carried out by heating a mixture of a substituted benzaldehyde, dimethone and 1.1 equiv. of kojic acid in the presence of nano- $\mathrm{Bi}_{2} \mathrm{O}_{3}-\mathrm{ZnO}(0.03 \mathrm{~g}, 2.8 \mathrm{~mol} \%$ of $\mathrm{Bi})$ at $100{ }^{\circ} \mathrm{C}$ for $2 \mathrm{~h}$, to afford chromenes 
3a-h in 75-84\% yields. The results are summarized in Table 2. As shown in Table 2, not only electronwithdrawing substituted benzaldehydes, such as $\mathrm{Cl}$ and $\mathrm{NO}_{2}$ substituted benzaldehydes afforded corresponding desired products in high yields, but also electron donating substituted benzaldehydes, 4$\mathrm{Me}$ and 4-MeO substituted benzaldehydes worked well under the reaction conditions.

Table 1. Optimization of the reaction conditions ${ }^{\mathrm{a}}$

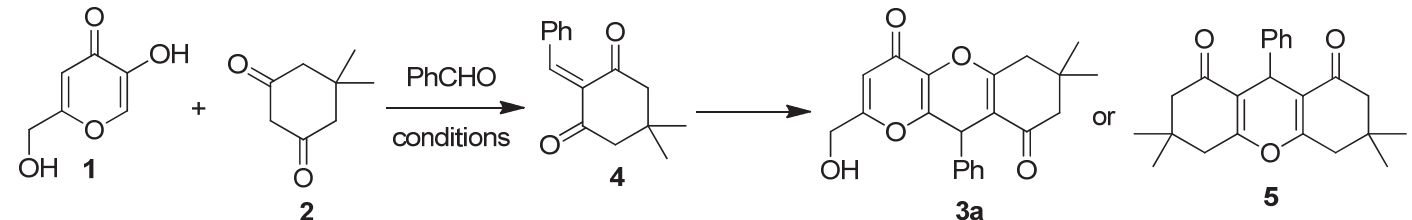

\begin{tabular}{|c|c|c|c|c|c|c|}
\hline Entry & Catalyst & $\begin{array}{l}\text { Catalyst loading } \\
\text { (g) }[\mathrm{Bi} \text { mol\% }]^{\mathrm{b}}\end{array}$ & Solvent & $\begin{array}{c}\text { Temp. } \\
\left({ }^{\circ} \mathrm{C}\right)\end{array}$ & $\begin{array}{l}\text { Time } \\
\text { (h) }\end{array}$ & $\begin{array}{l}\text { Yield } \\
(\%)\end{array}$ \\
\hline 1 & Nano- $\mathrm{Bi}_{2} \mathrm{O}_{3}-\mathrm{ZnO}$ & $0.03[2.8]$ & $\mathrm{EtOH}$ & Reflux & 6 & 40 \\
\hline 2 & Nano- $\mathrm{Bi}_{2} \mathrm{O}_{3}-\mathrm{ZnO}$ & $0.03[2.8]$ & Water & Reflux & 6 & $<10 \%{ }^{\mathrm{d}}$ \\
\hline 3 & Nano- $\mathrm{Bi}_{2} \mathrm{O}_{3}-\mathrm{ZnO}$ & $0.03[2.8]$ & $\mathrm{CH}_{2} \mathrm{Cl}_{2}$ & Reflux & 6 & 23 \\
\hline 4 & Nano- $\mathrm{Bi}_{2} \mathrm{O}_{3}-\mathrm{ZnO}$ & $0.03[2.8]$ & $\mathrm{MeCN}$ & Reflux & 6 & $\mathrm{NR}^{\mathrm{e}}$ \\
\hline 5 & Nano- $\mathrm{Bi}_{2} \mathrm{O}_{3}-\mathrm{ZnO}$ & $0.03[2.8]$ & $\mathrm{SF}^{\mathrm{c}}$ & 100 & 2 & $80,78,78,72^{f}$ \\
\hline 6 & Nano- $\mathrm{Bi}_{2} \mathrm{O}_{3}-\mathrm{ZnO}$ & $0.03[2.8]$ & $\mathrm{SF}$ & $\mathrm{rt}$ & 8 & NR \\
\hline 7 & Nano- $\mathrm{Bi}_{2} \mathrm{O}_{3}-\mathrm{ZnO}$ & $0.03[2.8]$ & SF & 60 & 8 & 27 \\
\hline 8 & Nano- $\mathrm{Bi}_{2} \mathrm{O}_{3}-\mathrm{ZnO}$ & $0.03[2.8]$ & SF & 80 & 5 & 64 \\
\hline 9 & Nano- $\mathrm{Bi}_{2} \mathrm{O}_{3}-\mathrm{ZnO}$ & $0.03[2.8]$ & SF & 110 & 2 & 66 \\
\hline 10 & - & - & $\mathrm{SF}$ & 100 & 6 & NR \\
\hline 11 & Nano- $\mathrm{Bi}_{2} \mathrm{O}_{3}-\mathrm{ZnO}$ & $0.01[0.9]$ & $\mathrm{SF}$ & 100 & 2 & 58 \\
\hline 12 & Nano- $\mathrm{Bi}_{2} \mathrm{O}_{3}-\mathrm{ZnO}$ & $0.02[1.8]$ & SF & 100 & 2 & 70 \\
\hline 13 & Nano- $\mathrm{Bi}_{2} \mathrm{O}_{3}-\mathrm{ZnO}$ & $0.05[4.7]$ & SF & 100 & 2 & 81 \\
\hline 14 & Nano-ZnO & $0.03[0.0]$ & SF & 100 & 2 & 20 \\
\hline 15 & $\mathrm{BiCl}_{3}$ & $0.02[6.3]$ & $\mathrm{SF}$ & 100 & 2 & $35^{\mathrm{g}}$ \\
\hline
\end{tabular}

${ }^{\mathrm{a}}$ Reactions were performed using dimethone $(1 \mathrm{mmol})$, benzaldehyde $(1 \mathrm{mmol})$ and kojic acid $(1.1 \mathrm{mmol}) ;{ }^{\mathrm{b}} \mathrm{The} \mathrm{mol} \%$ of Bi was calculated using EDX analysis data as $19.28 \mathrm{w} \% \mathrm{Bi}$ content of the catalyst; ${ }^{\mathrm{C}} \mathrm{SF}=$ Solvent-free; ${ }^{\mathrm{d} K n o e v e n a g e l ~ p r o d u c t ~} \mathbf{4}$ was obtained as major product; ${ }^{\mathrm{e}} \mathrm{NR}=\mathrm{No}$ reaction; ${ }^{\text {f}}$ Yields for runs with recovered catalyst. ${ }^{g}$ Octahydroxanthene $\mathbf{5}$ was obtained as major product.<smiles>CC1(C)CC(=O)CC(=O)C1</smiles><smiles>CC1(C)CC(=O)C2=C(C1)Oc1c(oc(CO)cc1=O)C2Br</smiles>

Scheme 1. Nano $\mathrm{Bi}_{2} \mathrm{O}_{3}-\mathrm{ZnO}$-catalyzed synthesis of pyrano-chromenes

Table 2. Nano- $\mathrm{Bi}_{2} \mathrm{O}_{3}-\mathrm{ZnO}$ catalyzed synthesis of dihydropyrano $[3,2-b]$ chromenediones $^{\mathrm{a}}$

\begin{tabular}{llcccc}
\hline \multirow{2}{*}{ Entry } & \multirow{2}{*}{$\mathrm{Ar}$} & \multirow{2}{*}{ Product } & \multirow{2}{*}{ Yield $(\%)$} & \multicolumn{2}{c}{$\mathrm{Mp}\left({ }^{\circ} \mathrm{C}\right)$} \\
\cline { 5 - 6 } & & $\mathbf{3 a}$ & 80 & Measured & Reported \\
\hline 1 & $\mathrm{C}_{6} \mathrm{H}_{5}$ & $\mathbf{3 b}$ & 82 & $186-188$ & $184-185[14]$ \\
2 & $4-\mathrm{ClC}_{6} \mathrm{H}_{4}$ & $\mathbf{3 c}$ & 79 & $218-220$ & $205-206[14]$ \\
3 & $2-\mathrm{ClC}_{6} \mathrm{H}_{4}$ & $\mathbf{3 d}$ & 84 & $214-216$ & $212-213[14]$ \\
4 & $3-\mathrm{NO}_{2} \mathrm{C}_{6} \mathrm{H}_{4}$ & $\mathbf{3 e}$ & 81 & $233-235$ & $229-230[14]$ \\
5 & $4-\mathrm{NO}_{2} \mathrm{C}_{6} \mathrm{H}_{4}$ & $\mathbf{3 f}$ & 78 & $168-170$ & $166-167[14]$ \\
6 & $2,4-\mathrm{Cl}_{2} \mathrm{C}_{6} \mathrm{H}_{3}$ & $\mathbf{3 g}$ & 75 & $177-179$ & $178-179[14]$ \\
7 & $4-\mathrm{OMeC}_{6} \mathrm{H}_{4}$ & $\mathbf{3 h}$ & 77 & $216-217$ & $214-215[14]$ \\
\hline
\end{tabular}

The results encouraged us to investigate the synthesis of pyrano-pyran derivatives 7 via nano- $\mathrm{Bi}_{2} \mathrm{O}_{3}$ $\mathrm{ZnO}$ catalyzed three-component reaction between kojic acid, substituted benzaldehydes and malononitrile. By treatment of malononitrile with kojic acid and benzaldehyde in the presence of 
catalytic amount of nano- $\mathrm{Bi}_{2} \mathrm{O}_{3}-\mathrm{ZnO}$ at $100{ }^{\circ} \mathrm{C}$ for $5 \mathrm{~h}$, reaction did not proceed smoothly and only $24 \%$ yield of product was obtained, along with a complex mixture of byproducts. So, the reaction was examined under different conditions, including various solvents, temperatures and using other catalysts such as $\mathrm{BiCl}_{3}$ and nano- $\mathrm{ZnO}$. Conducting reaction with $0.03 \mathrm{~g}$ of nano- $\mathrm{ZnO}$ in refluxing EtOH resulted in formation of corresponding pyrano-pyran 7a in $94 \%$ yield, within $2 \mathrm{~h}$ of reaction time. Then, the scope of the reaction was investigated by reaction of variety of aromatic aldehydes, in which the corresponding pyrano-pyrans 7a-f were obtained in $81-95 \%$ yields (Scheme 2, and Table 3 ).

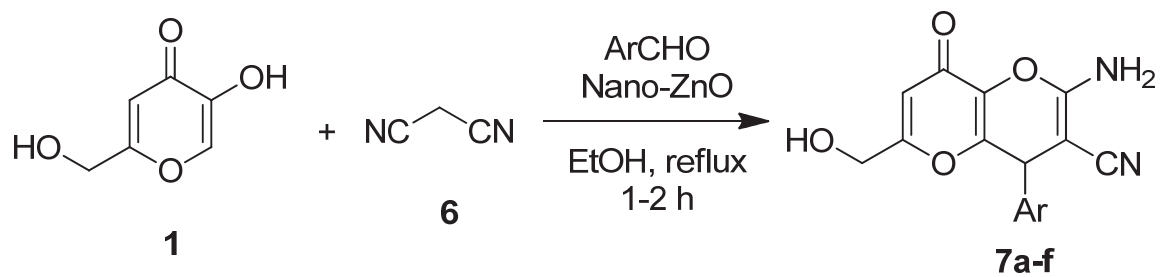

Scheme 2. Nano-ZnO-catalyzed synthesis of pyranopyrans

Table 3. Nano- $\mathrm{ZnO}$ catalyzed synthesis of aminopyrano-pyrans ${ }^{\mathrm{a}}$

\begin{tabular}{llcccc}
\hline \multirow{2}{*}{ Entry } & \multirow{2}{*}{$\mathrm{Ar}$} & \multirow{2}{*}{ Product } & Yield (\%) & \multicolumn{2}{c}{ Mp $\left({ }^{\circ} \mathrm{C}\right)$} \\
\cline { 5 - 6 } & & $\mathbf{2}$ & 94 & $222-224$ & Reported \\
\hline 1 & $\mathrm{C}_{6} \mathrm{H}_{5}$ & $\mathbf{7 b}$ & 90 & $220-222[15]$ \\
3 & $4-\mathrm{BrC}_{6} \mathrm{H}_{4}$ & $\mathbf{7 c}$ & 95 & $238-240$ & $228-230[16]$ \\
4 & $3-\mathrm{NO}_{2} \mathrm{C}_{6} \mathrm{H}_{4}$ & $\mathbf{7 d}$ & 81 & $220-222$ & New \\
5 & $3,4-\left(\mathrm{OCH}_{2} \mathrm{O}\right) \mathrm{C}_{6} \mathrm{H}_{3}$ & $\mathbf{7 e}$ & 88 & $258-260$ & New \\
6 & $1-$ naphthyl & $\mathbf{7 f}$ & 85 & $231-233$ & $235-237[15]$ \\
\hline
\end{tabular}

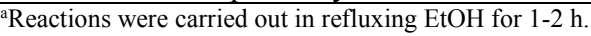

A plausible reaction mechanism involves the nano- $\mathrm{Bi}_{2} \mathrm{O}_{3}-\mathrm{ZnO}$ induced enolization of dimethone via hydrogene bond or coordination to $\mathrm{Bi}$ atom (a), which attached to hydrogen bond activated aldehyde (b) to give intermediate I. Water removing from I led to knoevenagel intermediate II (c), which underwent conjugate addition with kojic acid, activated with hydrogen bond with $\mathrm{Bi}=\mathrm{O}(\mathrm{d})$, to generate intermediate III. Intermediate III was converted to final product $\mathbf{V}$ by intramolecular cyclization to IV (e), followed by water removal (f). As shown in Scheme 3, the Zn-O-Bi-O bonds, produced as hydrat form of $\mathrm{Bi}_{2} \mathrm{O}_{3}$ on nano- $\mathrm{ZnO}$, and hydrogen bonds formed between starting components and also in-situ generated intermeditaes, played an important role in catalytic activity of $\mathrm{Bi}_{2} \mathrm{O}_{3}-\mathrm{ZnO}$, for this type of transformation. As mentioned above (Table 1, entry 14), the $\mathrm{Bi}_{2} \mathrm{O}_{3}$ is essential for the reaction of dimethone, benzaldehyde and dimethone. Due to the high reactivity of malononitrile, in the presence of $\mathrm{Bi}_{2} \mathrm{O}_{3}-\mathrm{ZnO}$ the reaction is uncontrollable, leading to a complex mixture. While nano- $\mathrm{ZnO}$ in the absence of $\mathrm{Bi}_{2} \mathrm{O}_{3}$ exhibited acceptable catalytic acitivity.

The comparison of the catalytic activity of nano- $\mathrm{Bi}_{2} \mathrm{O}_{3}-\mathrm{ZnO}$ in the three-component reaction of aromatic aldehydes, kojic acid and dimethone with some of the reported catalytic systems was summarized in Table 4. However the reaction temperatures and yields of the products are comparable, but due to the low mol\% of catalyst loading, nano- $\mathrm{Bi}_{2} \mathrm{O}_{3}-\mathrm{ZnO}$ is efficient and effective catalytic system. In the case of cyclocondensation of aromatic aldehydes, kojic acid and malononitrile using nano- $\mathrm{ZnO}$, reaction temperature and times, along with the yields of the corresponding products are also comparable with reported ones. 
<smiles>CC1(C)CC(=O)CC(=O)C1</smiles>

or<smiles>CC1(C)CC(=O)C=CC(=O)C1</smiles>

$\mathrm{OH} \mathrm{rO}_{1}^{1} \quad \mathrm{O}^{\prime}$

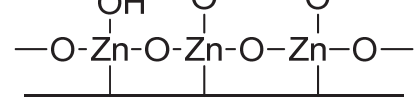

nano- $-\mathrm{Bi}_{2} \mathrm{O}_{3}-\mathrm{ZnO}$

(a)

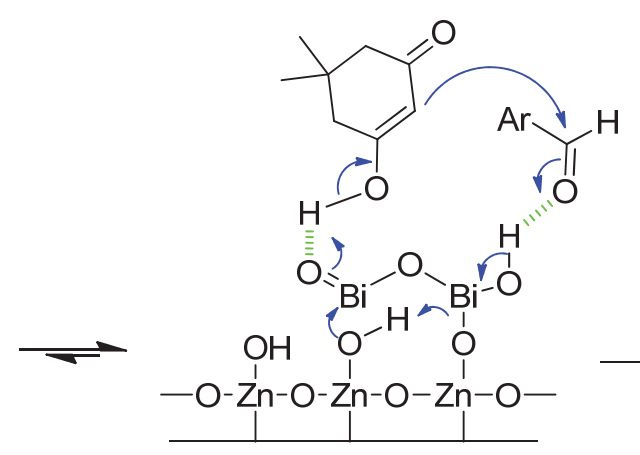

(b)

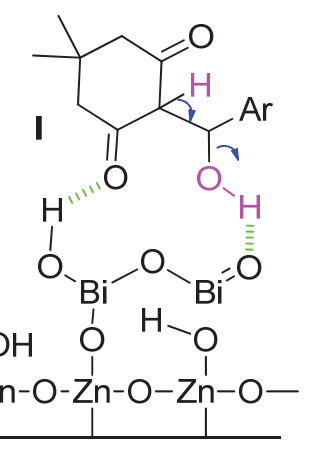

(c)

\section{Hydrogen Bond: Coordination:}

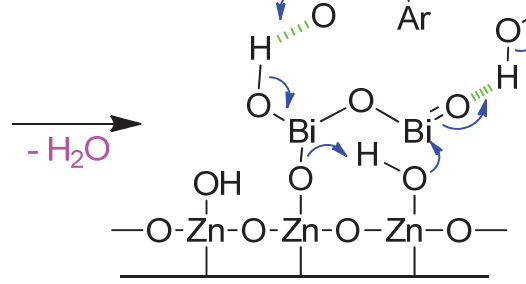

(d)

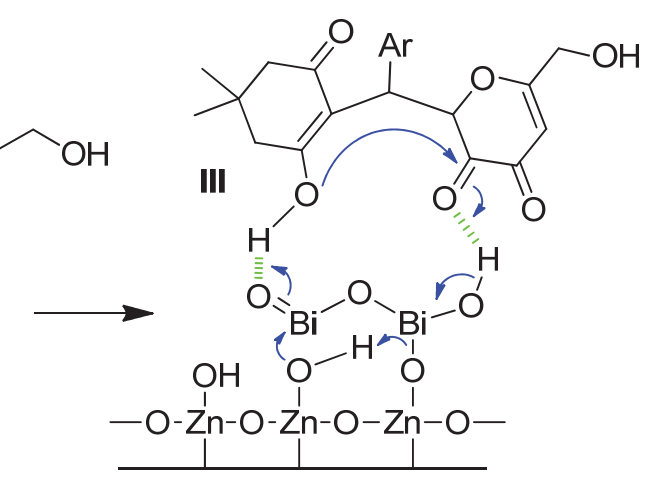

(e)

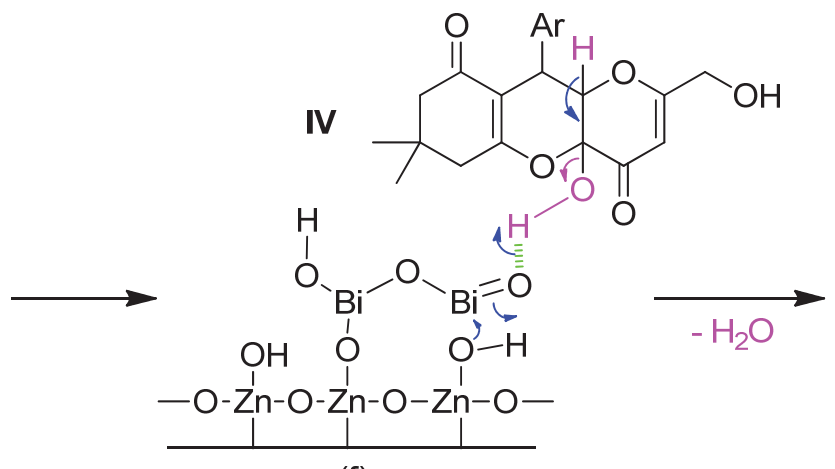

(f)<smiles>CC1(C)CC(=O)C2=C(C1)Oc1c(oc(CO)cc1=O)C2C1CCCCC1</smiles>

Scheme 3. Plausible reaction mechanism

Table 4. Comparison of the catalytic activity of nano- $\mathrm{Bi}_{2} \mathrm{O}_{3}-\mathrm{ZnO}$ with other catalysts.

\begin{tabular}{|c|c|c|c|c|c|}
\hline \multirow[t]{2}{*}{ Entry } & \multirow[t]{2}{*}{ Catalytic system } & \multicolumn{2}{|c|}{ Reaction conditions } & \multirow{2}{*}{$\begin{array}{l}\text { mol\% of catalyst } \\
\text { (catalyst loading) }\end{array}$} & \multirow[t]{2}{*}{ Yield $(\%)^{\text {ref }}$} \\
\hline & & Temperature $\left({ }^{\circ} \mathrm{C}\right)$ & Time $(\min )$ & & \\
\hline $1^{\mathrm{a}}$ & CAN & 120 & 30 & $10 \mathrm{~mol} \%$ & $94^{11}$ \\
\hline $2^{\mathrm{a}}$ & $\mathrm{FeCl}_{3}-\mathrm{SiO}_{2}$ & 100 & 60 & $5 \mathrm{~mol}_{0} \% \mathrm{FeCl}_{3}$ & $91^{15}$ \\
\hline $3^{\mathrm{a}}$ & $\mathrm{Bi}(\mathrm{OTf})_{3}$ & 120 & 20 & $5 \mathrm{~mol} \%$ & $91^{13}$ \\
\hline $4^{\mathrm{a}}$ & Alum & 100 & 50 & $10 \mathrm{~mol} \%$ & $94^{12}$ \\
\hline $5^{a}$ & $\mathrm{CeCl}_{3} \cdot 7 \mathrm{H}_{2} \mathrm{O}$ & 110 & 40 & $5 \mathrm{~mol} \%$ & $96^{14}$ \\
\hline $6^{\mathrm{a}}$ & $\mathrm{InCl}_{3}$ & 120 & 80 & $10 \mathrm{~mol} \%$ & $96^{10}$ \\
\hline $7^{\mathrm{a}}$ & Nano- $\mathrm{Bi}_{2} \mathrm{O}_{3}-\mathrm{ZnO}$ & 100 & 60 & $2.8 \mathrm{~mol}^{\%}$ of $\mathrm{Bi}^{3+}$ & $82^{\text {This work }}$ \\
\hline $8^{b}$ & $\mathrm{MCM}-41-\mathrm{SO}_{3} \mathrm{H}$ & Water, 90 & 50 & $30 \mathrm{mg}$ & $94^{36}$ \\
\hline $9^{\mathrm{b}}$ & Imidazole & EtOH, reflux & 90 & $20 \mathrm{~mol} \%$ & $88^{37}$ \\
\hline $10^{\mathrm{b}}$ & Nano-ZnO & EtOH, reflux & 90 & $30 \mathrm{mg}$ & $94^{\text {This work }}$ \\
\hline
\end{tabular}




\section{Conclusions}

In summary, $\mathrm{ZnO}$ and $\mathrm{Bi}_{2} \mathrm{O}_{3}-\mathrm{ZnO}$ nanoparticles were synthesized and characterized using FT-IR, XRD, SEM, EDX and TEM techniques. This the first report on the preparation of $\mathrm{Bi}_{2} \mathrm{O}_{3}$ supported on $\mathrm{ZnO}$ nanoparticles by simple hydrolyzing $\mathrm{BiCl}_{3}$ in the presence of $\mathrm{ZnO}$ nanoparticles. Threecomponent reaction of kojic acid, aldehyde and dimethone was catalyzed with nano- $\mathrm{Bi}_{2} \mathrm{O}_{3}-\mathrm{ZnO}$ and pyranochromenes were obtained in good to high yields. In the case of malononitrile, reaction was not progressed in the presence of nano- $\mathrm{Bi}_{2} \mathrm{O}_{3}-\mathrm{ZnO}$, but reaction catalyzed with nano- $\mathrm{ZnO}$ and pyranopyranes were produced in high yields. The recoverability of the catalyst was studied, in which the catalyst was reused in four further runs without loss of efficiency.

\section{Acknowledgements}

We are grateful to the Payame Noor University for financial support.

\section{Experimental}

\subsection{Material and Methods}

All chemicals were purchased from Merck and Sigma-Aldrich and used without any further purification. Solvents were used as received from commercial suppliers. NMR spectra were recorded using a Bruker instrument at $500 \mathrm{MHz}$ and $125 \mathrm{MHz}$ for proton and carbon nuclei, respectively, in $\mathrm{CDCl}_{3}$ or DMSO-d 6 . FT-IR spectra were measured as a $\mathrm{KBr}$ disc using a Win-Bomem, version 3.04 Galatic Industries Corperation, spectrometer. X-ray diffraction (XRD) patterns were measured using a Bruker D8 Advance with $\mathrm{CuK}(\alpha)$ radiation $(\lambda=0.15406 \mathrm{~nm})$ in the range $4^{\circ}<2 \theta<70^{\circ}$. Scanning electron microscope (SEM) images and EDX analysis were obtained using a VWGA3 TESCAN (20.0 KV) microscope. Transmission electron microscopy (TEM) images were recorded using a Philips CM120 microscope.

\subsection{Synthesis of nano- $\mathrm{ZnO}$}

$\mathrm{Zn}\left(\mathrm{NO}_{3}\right)_{2} .6 \mathrm{H}_{2} \mathrm{O}(1.0 \mathrm{~g})$ was dissolved in the solution of PEG $(1.5 \mathrm{~g})$ and ethanol $(20 \mathrm{ml})$ with constant stirring at $150^{\circ} \mathrm{C}$ until forming a viscous gel. After that the obtained viscous gel was dried at $350{ }^{\circ} \mathrm{C}$ for $30 \mathrm{~min}$, and then the dried precursors were ground into powder and calcined in air at 500 ${ }^{\circ} \mathrm{C}$ for $6 \mathrm{~h}$, to produce $\mathrm{ZnO}$ nanoparticles.

\subsection{Synthesis of nano- $\mathrm{Bi}_{2} \mathrm{O}_{3}-\mathrm{ZnO}$}

Nano-ZnO (1.46 g) was added to a solution of $\mathrm{BiCl}_{3}(0.63 \mathrm{~g})$ in $\mathrm{MeOH}(10 \mathrm{ml})$ and stirred at room temperature for $24 \mathrm{~h}$. Then, the solvent was evaporated and the obtained solid material was dried at room temperature in air, overnight.

\subsection{General procedure for the synthesis of pyrano-chromenes}

To a mixture of kojic acid $(1.1 \mathrm{mmol})$, dimethone $(1 \mathrm{mmol})$ and an aldehyde $(1 \mathrm{mmol})$ was added nano- $\mathrm{Bi}_{2} \mathrm{O}_{3}-\mathrm{ZnO}(0.03 \mathrm{~g})$ and stirred at $100{ }^{\circ} \mathrm{C}$ under solvent free condition for $1-2 \mathrm{~h}$. After completion of the reaction (monitored by TLC), $\mathrm{CH}_{2} \mathrm{Cl}_{2}$ was added and catalyst was removed by filtration. Solvent was evaporated and crude products were purified by flash chromatography on silica gel using hexaneacetone (7:3) as an eluent. Obtained products were characterized by FT-IR, NMR and melting points in comparison with authentic samples. 


\subsection{General procedure for the synthesis of pyrano-pyrans}

Nano- $\mathrm{ZnO}(0.03 \mathrm{~g})$ was added to a solution of kojic acid $(0.5 \mathrm{mmol})$, malononitrile $(0.5 \mathrm{mmol})$ and aldehyde $(0.5 \mathrm{mmol})$ in $\mathrm{EtOH}(10 \mathrm{~mL})$ and refluxed for $1-2 \mathrm{~h}$. After completion of the reaction (monitored by TLC), catalyst was separated by filtration, and the reaction mixture was cooled and desired product recrystallized from the solution. Obtained products were characterized by FT-IR, NMR and melting points in comparison with authentic samples.

\subsection{Physical and Spectral Data, for example:}

2-(hydroxymethyl)-7,7-dimethyl-10-phenyl-7,8-dihydropyrano[3,2-b]chromene-4,9(6H,10H)dione (3a): IR $(\mathrm{KBr}): v\left(\mathrm{~cm}^{-1}\right)=3361,3080,3025,2962,2929,1678,1667,1637,1441,1377,1219$, 1192, 1078, 955, 852, 712. ${ }^{1} \mathrm{H}-\mathrm{NMR}\left(500 \mathrm{MHz}, \mathrm{DMSO}-d_{6}\right): \delta=7.19-7.52(\mathrm{~m}, 5 \mathrm{H}, \mathrm{Ph}), 6.28(\mathrm{~s}, 1 \mathrm{H}$, $\mathrm{CH}$ pyrone), 5.66 (br, $1 \mathrm{H}, \mathrm{OH}), 4.79$ (s, $1 \mathrm{H}, \mathrm{CH}$ pyran), 4.07-4.20 (m, 2H, $\mathrm{CH}_{2}$ pyrone), 2.55-2.66 (m, 2H, $\left.\mathrm{CH}_{2}\right), 2.09-2.24\left(\mathrm{~m}, 2 \mathrm{H}, \mathrm{CH}_{2}\right), 1.02\left(\mathrm{~s}, 3 \mathrm{H}, \mathrm{CH}_{3}\right), 0.94\left(\mathrm{~s}, 3 \mathrm{H}, \mathrm{CH}_{3}\right) \mathrm{ppm}$.

10-(4-chlorophenyl)-2-(hydroxymethyl)-7,7-dimethyl-7,8-dihydropyrano[3,2-b]chromene4,9(6H,10H)-dione (3b): IR (KBr): $v\left(\mathrm{~cm}^{-1}\right)=3325,3095,2960,2927,1673,1641,1597,1443$, 1376, 1217, 1190, 1078, 852. ${ }^{1} \mathrm{H}-\mathrm{NMR}\left(500 \mathrm{MHz}, \mathrm{CDCl}_{3}\right): \delta=7.23-7.32(\mathrm{~m}, 4 \mathrm{H}, \mathrm{Ph}), 6.55(\mathrm{~s}, 1 \mathrm{H}$, $\mathrm{CH}$ pyrone), 4.92 (s, 1H, CH pyran), 4.39-4.48 (m, 2H, $\mathrm{CH}_{2}$ pyrone), 2.63-2.73 (m, $\left.2 \mathrm{H}, \mathrm{CH}_{2}\right), 2.21$ $2.32\left(\mathrm{~m}, 2 \mathrm{H}, \mathrm{CH}_{2}\right), 1.14\left(\mathrm{~s}, 3 \mathrm{H}, \mathrm{CH}_{3}\right), 1.08\left(\mathrm{~s}, 3 \mathrm{H}, \mathrm{CH}_{3}\right) \mathrm{ppm}$.

2-Amino-4,8-dihydro-6-(hydroxymethyl)-8-oxo-4-phenylpyrano[3,2-b]pyran-3-cabonitrile (7a): IR (KBr): $v\left(\mathrm{~cm}^{-1}\right)=3412,3356,3186,2194,1639,1597,1446,1406,1207 .{ }^{1} \mathrm{H}-\mathrm{NMR}(500 \mathrm{MHz}$, DMSO-d6): 7.38-7.41 (m, $2 \mathrm{H}, \mathrm{Ph}), 7.31-7.34$ (m, $1 \mathrm{H}, \mathrm{Ph}), 7.29-7.31(\mathrm{~m}, 2 \mathrm{H}, \mathrm{Ph}), 7.23\left(\mathrm{~s}, 2 \mathrm{H}, \mathrm{NH}_{2}\right)$, 6.33 (s, $1 \mathrm{H}, \mathrm{CH}$ pyrone), 5.68 (t, $J=6.2 \mathrm{~Hz}, 1 \mathrm{H}, \mathrm{OH}), 4.79$ (s, $1 \mathrm{H}, \mathrm{CH}$ pyran ), 4.21 (dd, $J=15.8$ $\mathrm{Hz}, J=6.2 \mathrm{~Hz}, 1 \mathrm{H}, \mathrm{CH}_{2}$ pyrone), 4.12 (dd, $J=15.8 \mathrm{~Hz}, J=6.2 \mathrm{~Hz}, 1 \mathrm{H}, \mathrm{CH}_{2}$ pyrone) ppm.

2-Amino-4-(benzo[d][1,3]dioxol-6-yl)-4,8-dihydro-6-(hydroxymethyl)-8-oxopyran[3,2-b]pyran3-carbonitrile (7d): IR (KBr): $v\left(\mathrm{~cm}^{-1}\right)=3000-3400,3309,3195,3074,2968,2897,2195,1644$, $1592,1489,1412,1248,1219 .{ }^{1} \mathrm{H}-\mathrm{NMR}\left(500 \mathrm{MHz}, \mathrm{DMSO}-d_{6}\right): 7.20\left(\mathrm{~s}, 2 \mathrm{H}, \mathrm{NH}_{2}\right), 6.91(\mathrm{~d}, J=7.0$ $\mathrm{Hz}, 1 \mathrm{H}, \mathrm{Ph}), 6.83(\mathrm{~s}, 1 \mathrm{H}, \mathrm{Ph}), 6.76(\mathrm{~d}, J=7.1 \mathrm{~Hz}, 1 \mathrm{H}, \mathrm{Ph}), 6.32$ (s, 1H, CH pyrone), 6.02 (s, 2H, $\left.\mathrm{CH}_{2}\right), 5.68(\mathrm{~s}, \mathrm{~b}, 1 \mathrm{H}, \mathrm{OH}), 4.72(\mathrm{~s}, 1 \mathrm{H}, \mathrm{CH}$ pyran $), 4.12-4.23\left(\mathrm{~m}, 2 \mathrm{H}, \mathrm{CH}_{2}\right) \mathrm{ppm} .{ }^{13} \mathrm{C}$ NMR $(125$ MHz, DMSO-d6): $\delta=40.3,56.2,59.7,101.3,107.7,108.9,114.5,119.3,126.7,140.5,141.1,146.7$, $148.1,155.9,159.1,169.3,169.9 \mathrm{ppm}$.

2-Amino-4,8-dihydro-6-(hydroxymethyl)-4-(naphthalene-1-yl)-8-oxopyrano[3,2-b]pyran-3carbonitrile (7e): IR (KBr): $v\left(\mathrm{~cm}^{-1}\right)=3000-3400,3299-3193,3061,2961,2188,1644,1592,1444$, 1412, 1267, 1216. ${ }^{1} \mathrm{H}-\mathrm{NMR}$ (500 MHz, DMSO-d6): 7.41-7.95 (m, 7H, CH naphthyl), 7.27 (s, 2H, $\left.\mathrm{NH}_{2}\right), 6.34$ (s, 1H, CH pyrone), $5.64(\mathrm{~s}, \mathrm{~b}, 1 \mathrm{H}, \mathrm{OH}), 4.98\left(\mathrm{~s}, 1 \mathrm{H}, \mathrm{CH}\right.$ pyran), 4.09-4.16 (m, 2H, $\left.\mathrm{CH}_{2}\right)$ ppm. ${ }^{13} \mathrm{C}$ NMR $\left(125 \mathrm{MHz}\right.$, DMSO- $\left.d_{6}\right): \delta=41.0,57.3,60.1,114.6,119.3,124.5,126.2,126.5,126.6$, $127.0,127.7,128.5,131.8,133.7,140.5,141.3,155.7,159.2,166.7,179.1 \mathrm{ppm}$. 


\section{References}

1 Domling A. (2006) Recent developments in isocyanide based multicomponent reactions in applied chemistry. Chem. Rev., 106 (1) 17-89.

2 Pratap R., and Ram V. J. (2014) Natural and synthetic chromenes, fused chromenes, and versatility of dihydrobenzo[ $h]$ chromenes in organic synthesis. Chem. Rev., 114 (20) 10476-10526.

3 Kumar D., Reddy V. B., Sharad S., Dube U., and Kapur S. (2009) A facile one-pot green synthesis and antibacterial activity of 2-amino-4H-pyrans and 2-amino-5-oxo-5,6,7,8-tetrahydro- $4 \mathrm{H}$ chromenes. Eur. J. Med. Chem., 44 (9) 3805-3809.

4 Shestopalov A. M., Litvinov Y. M., Rodinovskaya L. A., Malyshev O. R., Semenova M. N., and Semenov V. V. (2012) Polyalkoxy substituted $4 H$-chromenes: Synthesis by domino reaction and anticancer activity. ACS Comb. Sci., 14 (8) 484-490.

5 Bonsignore L., Loy G., Secci D., and Calignano A. (1993) Synthesis and pharmacological activity of 2-oxo-(2H) 1-benzopyran-3-carboxamide derivatives. Eur. J. Med. Chem., 28 (6) 517-520.

6 El-Nagger A. M., Abdel-El-Salam A. M., Latif M. S. A., and Ahmed F. S. M. (1981) Synthesis of some biologically active visnagin-9-sulfonylamino acid and dipeptide derivatives. Chemischer Informationsdienst. Pol. J. Chem., 55 793-797.

7 Evidente A., Andolfi A., Maddau L., Franceschini A., and Marras F. (2005) Biscopyran, a Phytotoxic Hexasubstituted Pyranopyran Produced by Biscogniauxia mediterranea, a Fungus Pathogen of Cork Oak. J. Nat. Prod., 68 (4) 568-571.

8 Sheldrake H. M., Jamieson C., and Burton J. W. (2006) The Changing Faces of Halogenated Marine Natural Products: Total Synthesis of the Reported Structures of Elatenyne and an Enyne from Laurencia majuscula. Angew. Chem. Int. Ed., 45 (43) 7199-7202.

9 Cakir S. P., Stokes S., Sygula A., and Mead K. T. (2009) Evidence for $\pi$-Stacking as a Source of Stereocontrol in the Synthesis of the Core Pyranochromene Ring System common to Calyxin I, Calyxin J, and Epicalyxin J. J. Org. Chem., 74 (19) 7529-7532.

10 Li Y., Meng X., Cai G., Du B., and Zhao B. (2014) CAN-catalyzed synthesis of 10-arylpyrano[3,2b]chromene-4,9-diones under solvent-free conditions. Res. Chem. Intermed., 40 (2) 699-709.

11 Subba Reddy B. V., Ramana Reddy M., Narasimhulu G. and Yadav J. S. (2010) $\mathrm{InCl}_{3}$-catalyzed three-component reaction: a novel synthesis of dihydropyrano[3,2-b]chromenediones under solventfree conditions. Tetrahedron Lett., 51 (43) 5677-5679.

12 Li W. L., Wu L. Q., and Yan F. L. (2011) Alum-catalyzed one-pot synthesis of dihydropyrano[3,2b]chromenediones. J. Braz. Chem. Soc., 22 (11) 2202-2205.

13 Pourshahrestani S. Mohammadpoor-Baltork I., Moghadam M., Tangestaninejad S., Khosropour A. R., and Mirkhani V. (2015) Bismuth triflate, $\mathrm{Bi}(\mathrm{OTf})_{3}$, as an efficient and reusable catalyst for synthesis of dihydropyrano[3,2-b]chromenediones. J. Iran. Chem. Soc., 12 (4) 573-580.

14 Zhang G., and Qu Y. (2013) $\mathrm{CeCl}_{3} \cdot 7 \mathrm{H}_{2} \mathrm{O} / \mathrm{SiO}_{2}$ as an efficient and recyclable catalyst for the synthesis of dihydropyrano[3,2- b]chromenediones. J. Chem., 1-4.

$15 \mathrm{Li}$ W. L., Liang J. Y., Wang T. B. and Yang Y. Q. (2011) $\mathrm{FeCl}_{3}-\mathrm{SiO}_{2}$ as heterogeneous catalysts for the preparation of dihydropyrano[3,2-b]chromenediones. Collect. Czech. Chem. Commun., 76 (12) 1791-1797.

16 Maleki A., and Azadegan S. (2017) Preparation and characterization of silica-supported magnetic nanocatalyst and application in the synthesis of 2-amino- $4 H$-chromene-3-carbonitrile derivatives. Inorg. Nano-Met. Chem., 47 (6) 917-924.

17 Banitaba S. H., Safari J., and Dehghan Khalili S. (2013) Ultrasound promoted one-pot synthesis of 2-amino-4,8-dihydropyrano[3,2-b]pyran-3-carbonitrile scaffolds in aqueous media: A 
complementary 'green chemistry' tool to organic synthesis. Ultrasonics Sonochem., 20 (1) 401-407. 18 Nasim Khan M. D., Pal S., Karamthulla S. and Choudhury L. H. (2014) Imidazole as organocatalyst for multicomponent reactions: diversity oriented synthesis of functionalized hetero- and carbocycles using in situ-generated benzylidenemalononitrile derivatives. RSC Adv., 4, 3732-3741.

19 Piaot M. Z., and Imafuku K. (1997) Convenient synthesis of amino-substituted pyranopyranones. Tetrahedron Lett., 38 (30) 5301-5302.

20 Shestopalov A. A., Rodinovskaya L. A., Shestopalov A. M. and Litvinov V. P. (2004) One-step synthesis of substituted 4,8-dihydropyrano[3,2-b]pyran-4-ones. Russ. Chem. Bull. Int. Ed., 53 (3) 724-725.

21 Shitole B., Shitole N., Shingare M., and Kakde G. (2016) An efficient one pot three-component synthesis of dihydropyrano[3,2-c]chromenes using ammonium metavanadate as catalyst. Curr. Chem. Lett., 5 (4) 137-144.

22 Lin C. H., Wu H. L. and Huang Y. L. (2007) Combining high-performance liquid chromatography with on-line microdialysis sampling for the simultaneous determination of ascorbyl glucoside, kojic acid, and niacinamide in bleaching cosmetics. Anal. Chim. Acta., 581 (1) 102-107.

23 Brtko J., Rondah L., Fickova M., Hudecova D., Eyb V., and Uher M. (2004) Kojic acid and its derivatives: history and present state of art. Cent. Eur. J. Pub. Health., 12, S16-S18.

24 Son S. M., Moon K. D. and Lee C. Y. (2001) Inhibitory effects of various antibrowning agents on apple slices. Food Chem., 73 (1) 23-30

25 Chen J. S., Wei C., Rolle R. S., Steven Otwell W., Balaban M. O. and Marshall M. R. (1991) Inhibitory effect of kojic acid on some plant and crustacean polyphenol oxidases. J. Agric. Food Chem., 39 (8) 1396-1401.

26 Buchta K. (1982) Organic acids of minor importance in biotechnology biomass, microorganisms for special application, microbial products, energy from renewable resources. Bioehringer, Ingelheim Federal Republic of Germany, 447.

27 Cao J., Zhu Y., Shi L., Zhu L., Bao K., Liu S., and Qian Y. (2010) Double-Shelled $\mathrm{Mn}_{2} \mathrm{O}_{3}$ Hollow Spheres and Their Application in Water Treatment. Eur. J. Inorg. Chem., 2010 (8) 1172-1176

28 Shinde S. S., Bhosale C. H., and Rajpure K. Y. (2011) Photocatalytic activity of sea water using $\mathrm{TiO}_{2}$ catalyst under solar light. J. Photochem. Photobiol. B: Biol., 103 (2) 111-117.

29 Maleki A., Aghaei M., Hafizi-Atabak H. R., and Ferdowsi M. (2017) Ultrasonic treatment of $\mathrm{CoFe}_{2} \mathrm{O}_{4} @ \mathrm{~B}_{2} \mathrm{O}_{3}-\mathrm{SiO}_{2}$ as a new hybrid magnetic composite nanostructure and catalytic application in the synthesis of dihydroquinazolinones. Ultrason. Sonochem., 37, 260-266.

30 Bao J., Zimmler M. A., and Capasso F. (2006) Broadband ZnO Single-Nanowire Light-Emitting Diode. Nano Lett., 6 (8) 1719-1722.

31 Eftekhari-sis B., and Zirak M. (2015) Chemistry of $\alpha$-Oxoesters: A Powerful Tool for the Synthesis of Heterocycles. Chem. Rev., 115 (1) 151-264.

32 Eftekhari-sis B., Zirak M., and Akbari A. (2013) Arylglyoxals in synthesis of heterocyclic compounds. Chem. Rev., 113 (5) 2958-3043

33 Zirak M., and Eftekhari-sis B. (2015) Kojic acid in organic synthesis. Turk. J. Chem., 39, 439-496.

34 Amini M., and Ashrafi M. (2016) Photocatalytic degradation of some organic dyes under solar light irradiation using $\mathrm{TiO}_{2}$ and $\mathrm{ZnO}$ nanoparticles. Nano. Chem. Res., 1 (1) 79-86.

35 Cerva H., and Russwurm W. (1988) Microstructure and crystal structure of bismuth oxide phases in zinc oxide varistor ceramics. J. Am. Ceram. Soc., 71 (7) 522-530.

36 Sarrafi Y., Mehrasbi E., and Mashalchi S. Z. (2015) MCM-41-SO3H: an efficient, reusable, heterogeneous catalyst for the one-pot, three-component synthesis of pyrano[3,2-b]pyrans. Res. 
Chem. Intermed., published online; doi: 10.1007/s11164-015-2275-z.

37 Khan M. N., Pal S., Karamthulla S., and Choudhury L. H. (2014) Imidazole as organocatalyst for multicomponent reactions: diversity oriented synthesis of functionalized hetero-and carbocycles using in situ-generated benzylidenemalononitrile derivatives. RSC Adv., 4 (8) 3732-3741.

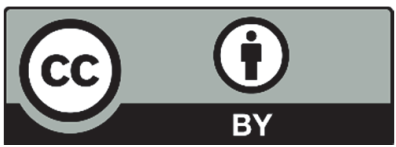

(C) 2016 by the authors; licensee Growing Science, Canada. This is an open access article distributed under the terms and conditions of the Creative Commons Attribution (CC-BY) license (http://creativecommons.org/licenses/by/4.0/). 